\title{
Analysis of User - Space Relations: Şehit Fethi Sekin Park Example, İzmir
}

\section{Emine MALKOÇ TRUE ${ }^{1 *}$, Çiğdem KILIÇASLAN²}

\begin{abstract}
It is important to analyze the relationship between the user and space by approaching the physical environment in a visual context, identifying existing and potential problems and proposing solutions to strengthen the public life of cities. Şehit Fethi Sekin Park, which also possesses sentimental values and love of homeland in its name, has been analyzed visually, and the design approach has been examined and the relationship between physical environment and user behaviour has been interpreted. The study was carried out in the example of Şehit Fethi Sekin Park in Bayraklı District of İzmir. In the first stage, the research area was generally photographed and the visual impressions were taken into consideration by the first impressions of the environment, the remarkable elements, the factors that reduce / increase the visual quality and the features that make the settlement different. In the second stage, the research area was evaluated in terms of spatial, sensory and social aspects. In the last stage, the research area was observed and photographed on the basis of environment - user - behaviour, and used and unused sections of the study area were determined. In addition, user behaviours and the physical environment in which this behaviours take place were handled together and the effects of environmental factors on user behaviours were revealed. As a result of the study, although it was tried to create interesting designs and sub-spaces, it was determined that the intended usage intensity could not be achieved and it was predicted that improvements that would not disturb the traditional structure of the study area would make significant contributions to the socialization of the public.
\end{abstract}

Keywords: Environmental psychology, User - space - behaviour relation, Şehit Fethi Sekin Park, public space.

\section{Kullanıcı - Mekan İlişkilerinin Analizi: Şehit Fethi Sekin Parkı Örneği, İzmir}

ÖZET: Fiziksel çevreye görsel bağlamda yaklaşarak kullanıcı ile mekan arasındaki ilişkiyi analiz etmek, mevcut ve potansiyel sorunları belirleyerek çözüm önerileri getirmek kentlerin kamusal yaşamını güçlendirmek adına önemlidir. İsminde aynı zamanda manevi değerleri ve vatan sevgisini barındıran park alanı, görsel yolla analiz edilmiş, tasarım yaklaşımı irdelenerek fiziksel çevre ile kullanıcı davranışları arasındaki ilişki yorumlanmıştır. Çalışma; İzmir ili Bayraklı İlçesi Şehit Fethi Sekin Parkı örneğinde yürütülmüştür. İlk etapta, araştırma alanı genel olarak fotoğraflanmış, görsel yolla gerçekleştirilen değerlendirmelerde, sözü edilen çevrenin, uyandırdığı ilk izlenimler ile dikkati çeken unsurlar, görsel kaliteyi azaltan / artıran faktörler ve yerleşimi farklı kılan özellikler dikkate alınmıştır. İkinci etapta; araştırma alanı mekânsal, duyumsal ve sosyal yönden değerlendirilmiştir. Son etapta ise araştırma alanı, çevre kullanıcı - davranış temelinde gözlemlenerek fotoğraflanmış, incelenen alanda kullanılan ve kullanılmayan bölümler saptanmıştır. Ayrıca kullanıcı davranışları ile bu davranışın geçtiği fiziksel çevre birlikte ele alınarak, çevresel etmenlerin kullanıcı davranışlarına etkisi ortaya konulmuştur. Çalışma sonucunda her ne kadar ilgi çekici tasarımlar ve alt mekanlar oluşturulmaya çalışılsa da hedeflenen kullanım yoğunluğunun sağlanamadığı belirlenmiş, çalışma alanının geleneksel yapısını bozmayacak iyileştirmelerin kent halkının sosyalleşmesi yönünde önemli katkılar sağlayacağı öngörülmüştür.

Anahtar Kelimeler: Çevre psikolojisi, Kullanıcı - mekan - davranış ilişkisi, Şehit Fethi Sekin Parkı, Kamusal mekan.

\footnotetext{
${ }^{1}$ Emine MALKOÇ TRUE (Orcid ID: 0000-0003-1235-1978) Ege Üniversitesi, Ziraat Fakültesi, Peyzaj Mimarlığı Bölümü, İzmir, Türkiye

2 Çiğdem KILIÇASLAN (Orcid ID: 0000-0002-4467-3739), Adnan Menderes Üniversitesi, Ziraat Fakültesi, Peyzaj Mimarlığı Bölümü, Aydın, Türkiye

*Sorumlu Yazar/Corresponding Author: Emine MALKOÇ TRUE, e-mail: eminemalkoc@hotmail.com
} 


\section{INTRODUCTION}

Space, which is a part of the environment, is defined as limited and a defined area with a number of surfaces in order to meet the physiological, psychological and social needs of the users (Ünver, 2007). The space is not only a place where the need for shelter is met, but also a means of regulating the relations of people with society and the physical environment that plays an active role in communicating with others (Kutlu, 2018). The relationship between architecture and human started with the desire to be safe and protected, which is one of the most basic instincts (Ünver, 2007). In this sense, space is shaped by adapting to the change and development of human needs, including many dimensions according to the psychology, culture and socio-economic levels of the people living in it (Kutlu, 2018). Space is a product of human, both physically and socially, and spaces that are physically constructed and reconstructed first are shaped by the meanings imposed on them by people (Güleç Solak, 2017). Since the task of architecture is to create liveable built environments for people, the interaction between human as a social being and the environment in which he lives has to be examined within the human-environment behaviour relationship (Uzunoğlu and Özer, 2014). However, today's modern architecture has moved away from its structure, which places people at the centre and leaves liveable spaces for future generations (Silahtaroğlu and Ergül, 2016).

People's mood and wellbeing are affected by various elements of the built environment including spatial allocations, lighting, access to nature, color, indoor air quality, noise, thermal comfort, user control of space, and preferred environment (Charnofsky, 2012). Consideration of the relationship between people and their environment starts with architectural or environmental determinism, where the physical environment has a determining influence on human behaviour. But, by negating the role of human agency and social influences, it assumes environment - people interaction is a one-way process (Carmona et. al, 2010). The interaction between users and the physical environment is interpreted on the basis of environmental psychology and both the effects of environment on the users' behaviours and the effects of the users' various activities on the physical and social environment are determined within these types of studies (Malkoç True et. al, 2014).

In this context, this study aims to analyze a built environment on the basis of environmental psychology, which is about the interrelation of space and the user of space, and to try a participatory method in this analysis process.

\section{MATERIAL AND METHODS}

\section{Research Material}

The park named after Fethi Sekin, a police officer who was martyred as a result of the terrorist incident in Izmir on January 5, 2017, was chosen as the research area in this study. Şehit Fethi Sekin Park is located in Mansuroğlu Quarter of Bayraklı district of İzmir City, between Ankara Street, Aliya İzzet Begovic Street, 286/10 Street and 286/6 Streets. The study area is $40.000 \mathrm{~m}^{2}$ and it is a neighbourhood park. The park, which was opened to public service on 04 February 2017, is surrounded by residential areas and commercial areas. In addition to pedestrian access to the research area and access by private vehicle, public transportation such as bus, metro, minibus is also available. Due to its easy accessibility and proximity to other public spaces, it addresses users of all ages from seven to seventy (Figures 1 and 2). 


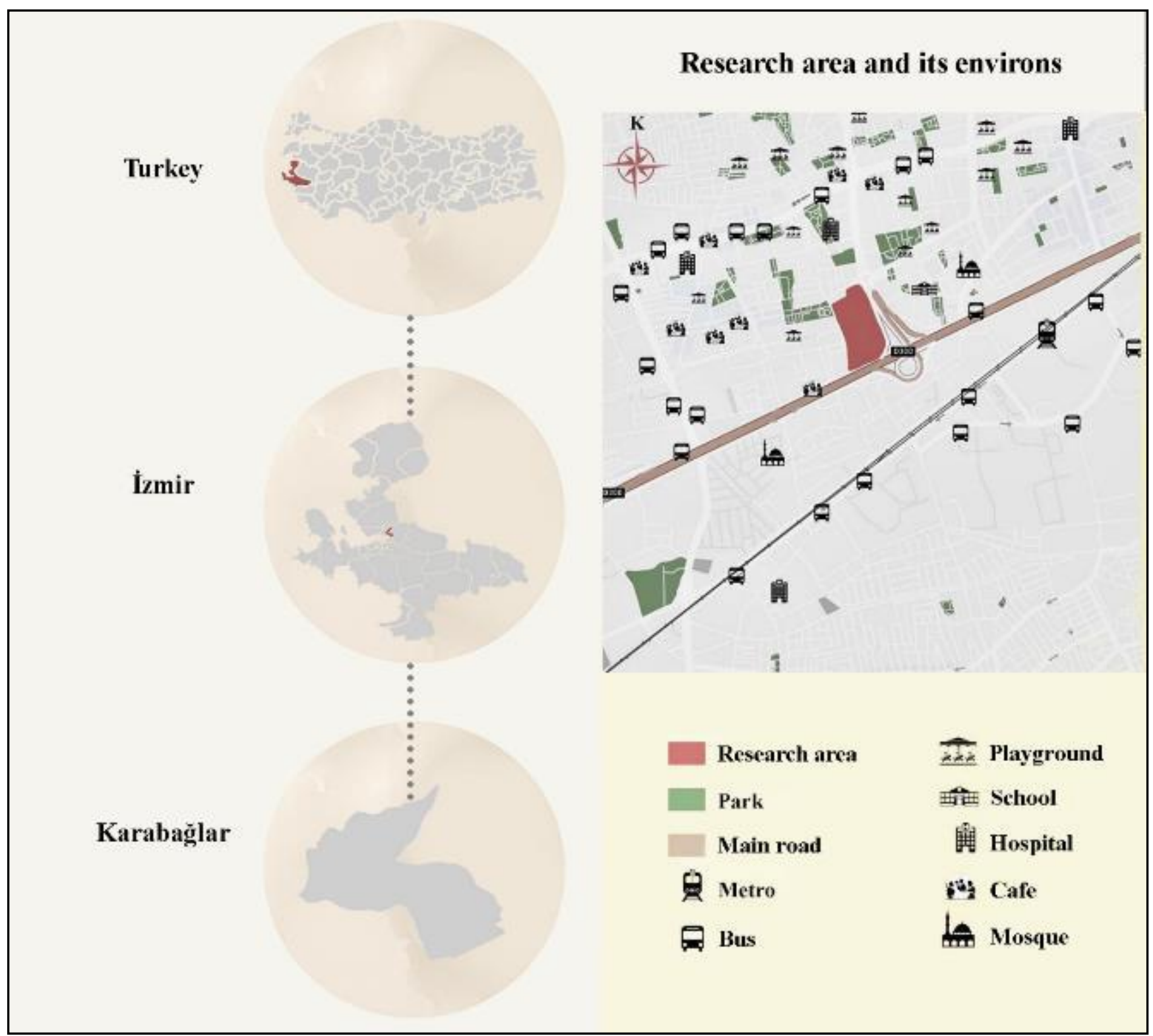

Figure 1. The study area and its vicinity

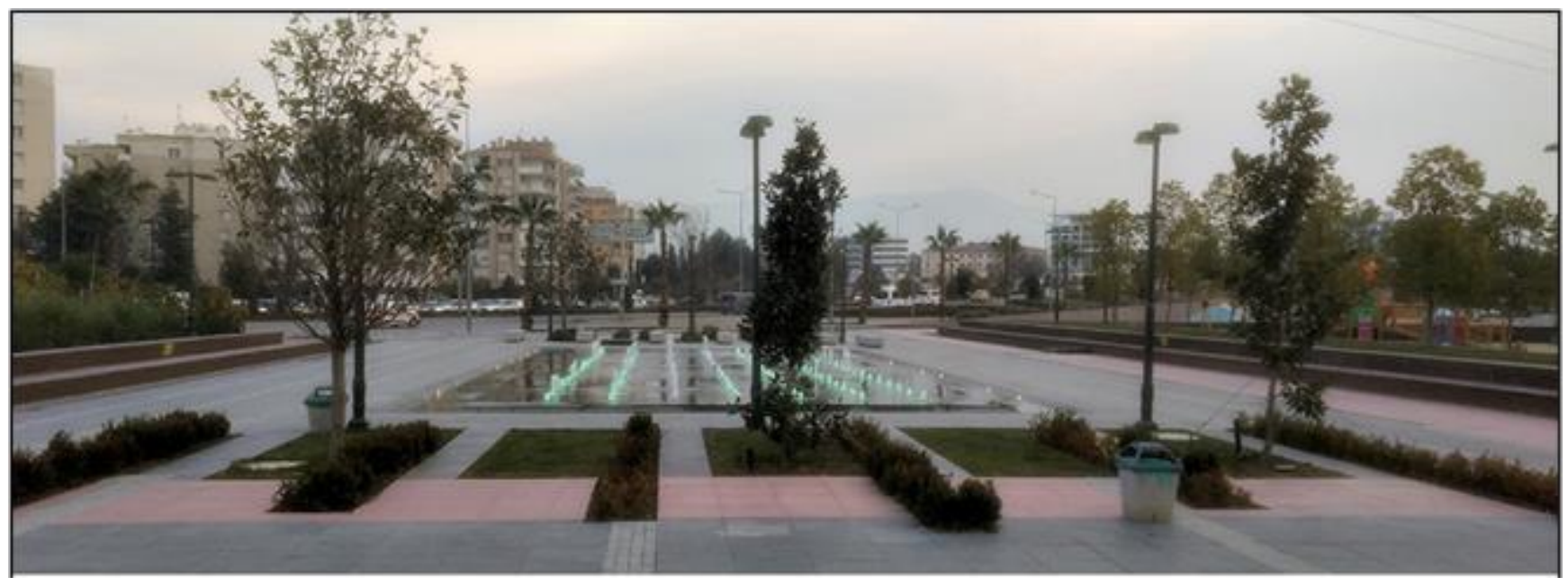

Figure 2. Photographs from the research area 


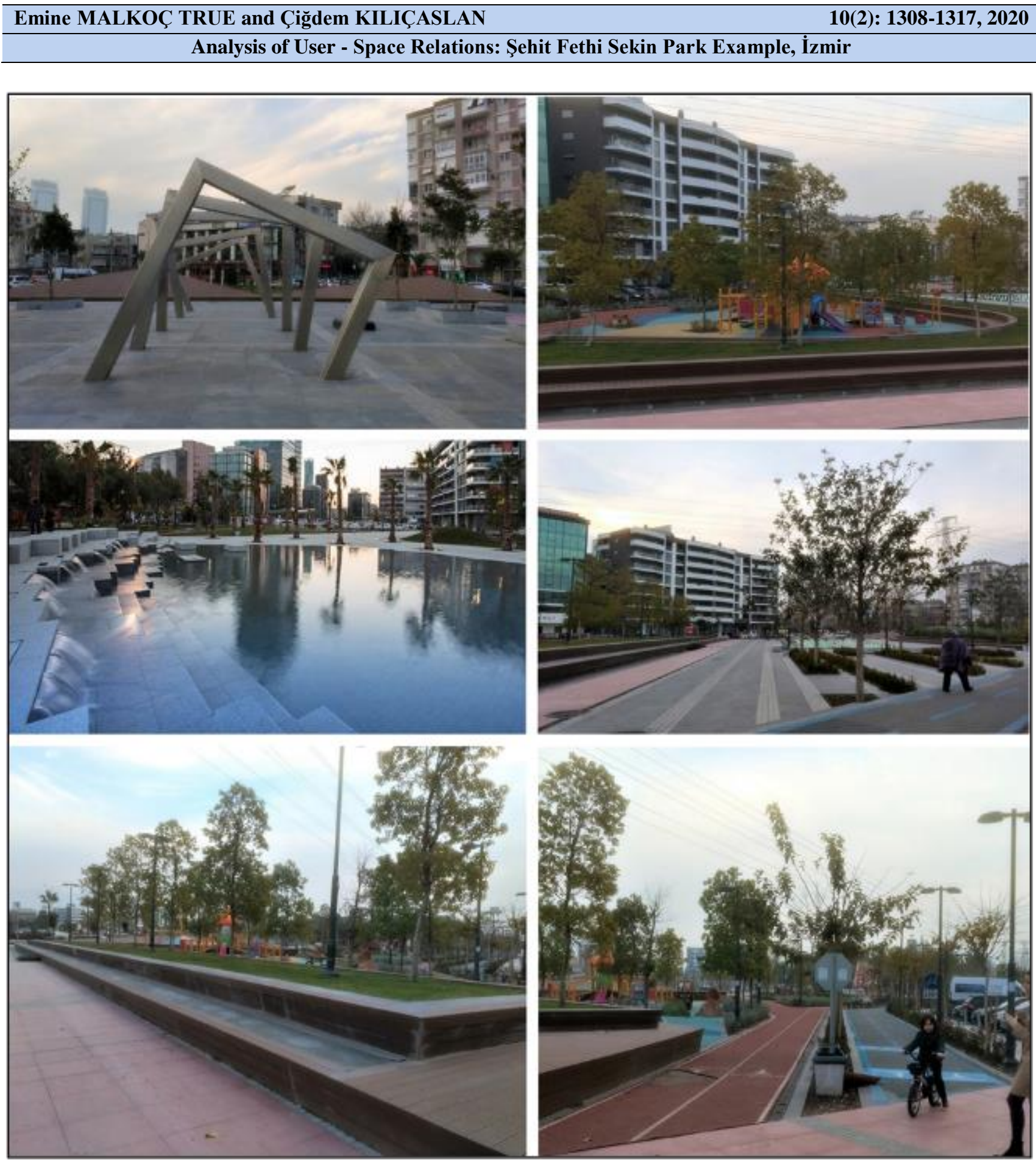

Figure 2. Photographs from the research area (continued)

\section{Research method}

The starting point of this study is to analyze the study area on the basis of user - space relations. The study was carried out as an end-of-term project within the scope of 2017-2018 Fall Semester Environmental Psychology course and 41 students (20 groups (1-3 persons)) participated in the study.

The research consists of four main stages:

- Characteristics of the Study Area: This stage consists of literature studies on the spatial characteristics of the study area and land observation studies to understand how the space is used.

- Data Collection: Visual analysis research method was used in the study and support was received from the senior students of the Department of Landscape Architecture of Ege University. Firstly, the students examined the study area on-site with the research team, followed by frequent field visits for 
their individual studies. During these visits, the students conducted observation studies under the guidance of the study preparation instructions given to them at the beginning of the semester. In the preparation of the "study preparation instructions", Malkoç (2008), Kilicaslan et al. (2008), Malkoc et al. (2010), Malkoc True et al. (2014), Malkoç True and Özkan (2014), Malkoç True and Sönmez Türel (2017) were used in this study.

"The study preparation instructions" originally prepared for this study consists of three main stages. In the first stage, the study area was observed in general (first impressions, factors affecting visual quality, characteristics that make the study area different). In the second stage, the spatial (building space / open space relationship, the quality of urban furniture, space transitions, existing subspace types, space action), sensorial (sensations in the perception process) and social (user information, social interaction types, activity types, user behaviour, environment - behaviour relationship) aspects of the study area were evaluated. In the last stage, the active / passive activities performed by the users were observed and interpreted, the used and unused parts of the area were mentioned together with their reasons and the effect of the positive / negative environmental factors on the user behaviours were revealed.

- Research Findings: The findings obtained from literature studies, field studies and observations and analysis studies were evaluated on the basis of environmental psychology.

- Evaluation and Conclusion: As a result of the evaluations, the results of the analysis were discussed on the basis of user - space relationship and some suggestions were made.

\section{RESULTS AND DISCUSSION}

\section{The $1^{\text {st }}$ Stage of the Research}

In the first stage of the study, the study area was generally photographed and evaluated visually. In the evaluations, it was benefitted from the first impressions of the students who have not experienced the study area before and the factors affecting the visual quality and the characteristics that make the study area different were determined. In this stage, the easily accessible location of the study area and contemporary and modern design have attracted attention. In addition, there are many cultural factors that affect the visual quality of the area positively or negatively. (Table 1).

Table 1. General evaluations

\begin{tabular}{|c|c|c|}
\hline $\begin{array}{c}\text { First } \\
\text { impressions }\end{array}$ & Positive & $\begin{array}{l}\text { - Easy access to the area and a variety of transportation alternatives } \\
\text { - Buffer between residential and commercial areas } \\
\text { - The design of the area is innovative, original and interesting. } \\
\text { - } \text { It embraces the society in general. } \\
\text { - Presence of sub-spaces encourages the use. } \\
\text { - It is rich in activities and facilities. } \\
\text { - The variety of materials is rich. } \\
\text { - Bikeway and walking trail promote space usage and does not affect other activities } \\
\text { - } \text { negatively. } \\
\text { - } \text { - } \text { Visualironment to the area } \\
\text { - Reliable and memoritive contribution of the modern and dynamic structure of the immediate } \\
\text { - Relaxing effect of water }\end{array}$ \\
\hline
\end{tabular}


Table 1. General evaluations (continued)

\begin{tabular}{|c|c|c|c|}
\hline & Negative & $\begin{array}{ll}\text { : } & \text { The } \\
\text { : } & \text { Ope } \\
\text { : } & \text { Insu } \\
\text { : } & \text { App } \\
\text { : } & \text { Neg } \\
\text { : } & \text { Exce } \\
\text { Only } & \text { Unb } \\
\text { : } & \text { Lack } \\
\text { - } & \text { Exis }\end{array}$ & $\begin{array}{l}\text { ng of space could not be created because of its high permeability } \\
\text { ence of noise as a negative environmental factor } \\
\text { negative climate factors } \\
\text { ent shading } \\
\text { ion / construction works still continue } \\
\text { image of destroyed and vandalized materials } \\
\text { e perception of the area from outside } \\
\text { entry is defined } \\
\text { ce in occupancy - emptiness relationship } \\
\text { nierarchy in space transitions } \\
\text { e of management related problems } \\
\text { e of insecurity }\end{array}$ \\
\hline \multirow{4}{*}{$\begin{array}{c}\text { Factors } \\
\text { affecting the } \\
\text { visual quality }\end{array}$} & & Natural & $\begin{array}{l}\text { - Presence and appropriate design of plant material } \\
\text { - Potential to benefit from sunlight }\end{array}$ \\
\hline & Positive & Cultural & $\begin{array}{l}\text { - } \text { Children's playgrounds } \\
\text { - } \text { Pater elements } \\
\text { - } \text { Seating places } \\
\text { - } \text { Grass hills } \\
\text { - } \text { Material colour harmony } \\
\text { - Night lighting } \\
\text { - Information and orientation in the area }\end{array}$ \\
\hline & & Natural & $\begin{array}{l}\text { - Presence of unkempt and young plant materials } \\
\text { - The perception of summery due to the presence of water elements }\end{array}$ \\
\hline & Negative & Cultural & $\begin{array}{l}\text { - Multi - storey building in the immediate surroundings } \\
\text { - } \text { Uresence of garbage in the area } \\
\text { - Existence of uncompleted parts in the park } \\
\text { - Electric pole and electricity line passing through the field } \\
\text { - Existence of drainage problem }\end{array}$ \\
\hline $\begin{array}{l}\text { Differentiating } \\
\text { characteristics } \\
\text { of the study } \\
\text { area }\end{array}$ & \multicolumn{3}{|c|}{$\begin{array}{l}\text { The area brings vitality and movement to the close environment, offers different experiences to its users, } \\
\text { and the contemporary and modern design approach takes the park to a different point among other parks } \\
\text { in İzmir. Moreover, the name given to the park has a positive psychological effect on the people of the } \\
\text { city. }\end{array}$} \\
\hline
\end{tabular}

\section{The $2^{\text {nd }}$ Stage of the Research}

The study area was evaluated in terms of spatial, sensory and social aspects. In the evaluations, it has been determined that the research area creates open space feeling spatially, and the urban furniture are highly qualified while the space transitions are gradual. In addition, it was realized that the area exhibited a very dynamic structure with the contribution of its sub-spaces (Table 2).

According to the sensory aspects of the study area; It was found to be roomy, attractive, proportionate and bright but it was considered to be unkempt and untraditional (Table 3).

In the social evaluations, it was seen that the users of the study area showed a homogeneous distribution in general as women and men and the users from all ages and segments of the society came to the area. Considering the types of social interaction seen in the area, one person, two people, parallel users and small groups were found to vary, but it was noticed that the use of two people gained weight. There are many active and passive activities in the study area and these behaviours are a part of daily 
life. In addition, when the user behaviours seen throughout the area are examined; self-focused, pure observer, verbal interaction and mobile users were observed and they are in harmony with the environment (Table 4).

Table 2. Spatial evaluations

\begin{tabular}{c|c|c|c}
\hline Built Space / Open Space & $1 / 4<$ & Space Transition & Gradual \\
\hline Action of the Space & \multicolumn{1}{|c|}{ Dynamic } & $\begin{array}{c}\text { Quality of } \\
\text { the Urban Furniture }\end{array}$ & High \\
\hline Sub - Spaces & $\begin{array}{l}\text { - Stone made watching terrace } \\
\text { - Playground } \\
\text { - Dry fountain }\end{array}$ & $\begin{array}{l}\text { - Square } \\
\text { - Hiking and cycling path }\end{array}$ \\
\hline
\end{tabular}

Table 3. Sensory evaluations

\begin{tabular}{c|c|c|c|c|c|c}
\hline & $\mathbf{1}$ & $\mathbf{2}$ & $\mathbf{3}$ & $\mathbf{4}$ & $\mathbf{5}$ & \\
\hline Closely spaced & & & & $\mathrm{X}$ & & Roomy \\
\hline Boring & & & & & $\mathrm{X}$ & Attractive \\
\hline Distributive & & & $\mathrm{X}$ & & & Relaxative \\
\hline Noisy & & & $\mathrm{X}$ & & & Quiet \\
\hline Irregular & & & $\mathrm{X}$ & & & Regular \\
\hline Disproportionate & & & & & $\mathrm{X}$ & Proportionate \\
\hline Unkempt & & $\mathrm{X}$ & & & & Well - kept \\
\hline Unsafe & & & $\mathrm{X}$ & & & Safe \\
\hline Dark & & & & & $\mathrm{X}$ & Bright \\
\hline Passive & & & $\mathrm{X}$ & & & Active \\
\hline Untraditional & $\mathrm{X}$ & & & & & Traditional \\
\hline Monotonous & & & $\mathrm{X}$ & & & Variable \\
\hline
\end{tabular}

Table 4. Social Evaluations

\begin{tabular}{|c|c|c|c|c|}
\hline \multirow{2}{*}{ User Information } & Gender & \multicolumn{3}{|c|}{ Female and male user distribution are homogeneous } \\
\hline & Age & \multicolumn{3}{|l|}{ All age groups } \\
\hline Social Interaction & \multicolumn{4}{|c|}{ Single person (SP), Two people (TP), Parallel user (PU) and Small Group (SG) } \\
\hline \multirow{2}{*}{ Activity Types } & Active & $\begin{array}{l}\text { - Dog walking } \\
\text { - Running } \\
\text { - Passing }\end{array}$ & $\begin{array}{l}\text { - Roller skating } \\
\text { - Playing games } \\
\text { - Walking }\end{array}$ & $\begin{array}{l}\text { - Photographing } \\
\text { - Cycling }\end{array}$ \\
\hline & Passive & $\begin{array}{l}\text { - Waiting } \\
\text { - Chatting } \\
\text { - Eating - Drinking }\end{array}$ & $\begin{array}{l}\text { - Seating } \\
\text { - Observing } \\
\text { - Resting }\end{array}$ & $\begin{array}{l}\text { - Listening to music } \\
\text { - Reading }\end{array}$ \\
\hline \multicolumn{2}{|c|}{ User Behaviour } & \multicolumn{3}{|c|}{ Self - Focused, Observing User, Verbally User, Active User } \\
\hline \multicolumn{2}{|c|}{ Environment-Behaviour Relationship } & \multicolumn{3}{|c|}{ User behaviour is compatible with the environment and is a part of daily life } \\
\hline
\end{tabular}




\section{The $3^{\text {rd }}$ Stage of the Research}

At this stage; the used and unused parts of the study area were identified and the relationship between the observed user behaviour and the environment throughout the area and the observed positive / negative environmental factors on the user behaviour were revealed.

"The Halide Edip Adıvar Primary School" and the "District Governor Özgür Azer Kurak Primary School" and many neighbourhood parks in the vicinity have a positive impact on the use of the area. In fact, Sakarya Street Park, which is located very close to the study area, establishes a continuity permanency - integrity relationship with the study area. In spite of this advantageous position, it has been observed that in particular the sections bordering the main road are not used. The main factors in not using these sections are noise and pollution from the road.

The design of the area (both the planting design and the structural design) was found original and interesting and the subspaces inside the park were found useful On the other hand, some handicaps of the design were also mentioned due to the environmental factors such as the presence of noise, being open to negative climate factors, insufficient shading and so on. In addition, some maintenance problems, such as garbage, unkempt urban furniture, and uncompleted parts affect the visual quality negatively.

Researches have shown that noise, air quality, lighting - colour characteristics can have an indirect effect on mental health in terms of socialization by influencing the communication skills and behaviours of the person in the psycho - social process as well as the direct effect on human health (Kutlu, 2018). The roomy structure of the pedestrian and walking paths in the research area positively affects the use, and the presence of items worth taking pictures (eikon, dry fountain, amphitheatre, etc.) directs users to this activity. Although the main road bounded to the area and the high-rise buildings in the immediate surroundings do not have a picturesque view, the accessible design approach is another factor that positively affects the use of the area. The presence of large open spaces separates users from each other and the lack of sufficiently defined entries of the area and the high permeability of the park borders allows the users to enter the area from different points. In addition, the open space fogging arcade at the main entrance was found to be interesting but not functional. The lighting system positively affects the use of the night, but it is determined that the intended usage intensity cannot be achieved even though interesting designs and sub-spaces are tried to be created. One of the most important reasons for this is the fact that the season passes are not taken into consideration much and the spatial solutions that make the user feel more comfortable during periods of adverse climate conditions are not designed. Therefore, particularly user density varies depending on the season and affects the length of stay in the park.

\section{CONCLUSION}

The research area is indispensable for Bayraklı District of İzmir with its easily accessible location and structure that embraces the society in general. Considering the dense settlement in the immediate vicinity, the study area acts as a buffer between the residential and commercial areas.

The biggest importance of the park is due to its name, which increases its value. The name 'Fethi Sekin' affects people emotionally positively, which causes people to protect the values of the park.

In this study, some suggestions have been made in order to determine the problems experienced in user - space relations of the park, which has such importance for its close environment, and to improve the use of space in this direction.

As it's mentioned in the literature, the physical environment created by urban design decisions directly affects the psychological, physical and social health of the individual, in turn, society as a whole (Uslu, Kiper, Baris, 2009) and so the use of the space is affected. Supporting the previous literature, 
when the results obtained from the findings were evaluated, the high level of boundary permeability and the high degree of perception of the area from outside creates a feeling of insecurity on the users. In addition, noise is often mentioned as a negative environmental factor. With the revisions to be made in the area, both the park boundaries should be better defined and the perception from the environs should be limited.

Studies on open spaces have investigated the relative influence of wind and temperature on user comfort (Walton, Dravitzki and Donn, 2007).. Similarly, climate factors have influenced the users in the research area as it is unprotected in terms of climate factors such as sun, wind and rain. This situation affects the usage intensity of the area negatively, especially in winter months. Therefore, urban furniture that provide opportunities such as shading and rain protection should be used in the area. The solutions to be produced in this direction will affect the use of the area in a positive way.

Being unkempt is also one of the main problems of the area. Although the park was recently opened to public use in 2017 , it is thought provoking that there are maintenance problems.

Especially considering the uses in the immediate surroundings, social and cultural activities should be supported, partial deformations of the floor and other materials should be repaired, the application of unfinished parts should be completed as soon as possible, drainage problems should be solved and routine maintenance should be performed.

When the research area is evaluated spatially, it is found rich and dynamic with its sub-spaces. Existing trees in the area contribute to the formation of space feeling and play an important role in strengthening the identity of the space. The structural materials used in the study area were found to be of high quality but were evaluated as unkempt in the evaluations. In addition, the presence of garbage that can be seen throughout the area shows that maintenance and management services gain a special importance at this point. As it's mentioned before, the name "Fethi Sekin" has an important place in people's value judgements. In this context, in terms of social and emotional values, careful attention must be paid to the maintenance of public places by the local government where a martyr hero like Fethi Sekin is named, routine maintenance of the park should be made.

The contribution of the study area to socialization is undoubtedly quite successful. However, the development of new solutions that will contribute to the social development of the society will positively affect the development of user - space relations.

\section{REFERENCES}

Uslu, A, Kiper, T and Baris, ME, 2009. Public Health - Urban Landscaping Relationship and User's Perceptions, Biotechnology \& Biotechnological Equipment, 23:3, 1399 - 1408

Carmona, M, Tiesdall, S, Heath, T and Oc, T, 2010. Public Places - Urban Spaces The Dimensios of Urban Design. Elsevier, ISBN - 13: 978-1-85617-827-3, Second Edition, 394 p.

Charnofsky, L, 2012. The Interrelationship Between Human Behavior and Sustainability in the Built Environment. Kent State University, College of Architecture and Environmental Design, Bachelor's Thesis, $61 \mathrm{p}$.

Güleç Solak, S, 2017. Space - Identity interaction: A Conceptual and theorical overview. Manas Journal of Social Studies, 2017, Vol: 6, No:1, Pages: 13 - 37.

Kilicaslan, C, Malkoc, E, Sonmez Turel, H, 2008. Comparative Analysis of Traditional, Modern, and Renovated Streets in Physical, Visual, and Life Aspects; A Case Study on Buca District - Izmir (Turkey). Indoor and Built Environment 2008, 17;5: 403 - 413.

Kutlu, R, 2018. The Effects of environmental factors on space quality and human health. The Turkish Online Journal of Design, Art and Communication - TOJDAC, January 2018 Volume 8, Issue 1, p. 67 - 78. 
Malkoc, E, Kilicaslan, C, Ozkan, MB, 2010. Visual Landscape Analysis of Urban Open Spaces: A Case Study of the Coastline of Göcek Settlement, Muğla, Türkiye. Indoor and Built Environment 2010, 19;5: 520 - 537.

Malkoç True, E, Altuğ Turan, İ, Sönmez Türel, H, Kalaycı, A, 2014. The Analysis of User - Space Relations in Terms of Environmental Psychology: Urla Urban Settlement. 25th International Scientific Experts Congress Agriculture and Food Industry, 25 - 27 September 2014, İzmir, Turkey, p: 177 - 180.

Malkoç True, E, Özkan, MB, 2014. Evaluation of a Public Open Space Depending on User Behaviour in the Post Occupancy Phase. Artium, Vol. 2, No.1, 16 - 28, 2014.

Malkoç True, EM, Sönmez Türel, H, 2017. Analysis of a public place in the view of project for public spaces’ The Place Diagram. Ege Üniv. Ziraat Fak. Derg., 2017, 54 (3):319 - 326.

Malkoç, E, 2008. Post - Occupancy evaluation (POE) in public spaces: A Case study of İzmir Konak Square and its vicinity. Ege University, Graduate School of Natural and Applied Science, Ph.D Thesis (Printed).

Silahtaroğlu, G, Ergül, H, 2016. A Study on the two parameter homothetic motions in hyperbolic plane. Beykent University Journal of Science and Engineering, Volume 9(2) 2016, 95 - 124.

Uzunoğlu, SS, Özer, H, 2014. A Model for the development of architectural phychology formation in architectural education. Megaron 2014; 9(2): 143 - 165.

Ünver, E, 2007. Evolution and transformation of Wall due to progress in time and technology. İstanbul Technical University, Institute of Science and Technology, Master Thesis (Printed).

Walton, D, Dravitzki, V, and Donn, M, 2007. The Relative Influence of Wind, Sunlight and Temperature on User Comfort in Urban Outdoor Spaces. Building and environment, 42(9), 3166 - 3175. 